\title{
Multiple Trauma in a 5 Years Child with a Longitudinal Follow Up
}

Luciana Reichert da Silva Assunção', Karina Gerhardt Bianco', Pedro Ivo Santos Silva ${ }^{3}$, Carla Oliveira Favretto ${ }^{1}$ and Robson Frederico Cunha 2*

${ }^{1}$ Post doctoral student, School of Dentistry of Araçatuba, - UNESP - Univ Estadual Paulista, Araçatuba, São Paulo, Brazil

${ }^{2}$ Adjunct professor, Department of Pediatric and Social Dentistry, School of Dentistry of Araçatuba, - UNESP - Univ Estadual Paulista, Araçatuba, São Paulo, Brazil

${ }^{3}$ Post doctoral student in the Department of Surgery, School of Dentistry of Araçatuba, - UNESP - Univ Estadual Paulista, Araçatuba, São Paulo, Brazil

\begin{abstract}
Dental-alveolar trauma in the primary dentition associated with intra-cranial injuries is not common. This article reports the management of a complex trauma involving cranial trauma and multiple luxations and avulsions of primary teeth in a five-year old boy as a consequence of a horse kick. The treatment, including the hospital intervention and dentistry procedures, is described. The clinical outcomes are reported at a 5-year follow-up.
\end{abstract}

Keywords: Trauma; Orthodontics; Radiology

\section{Introduction}

Many studies concerning trauma in primary teeth report the involvement of only one tooth as the most common event. Episodes involving extensive trauma in permanent teeth have been widely reported, but there are not many reports involving extensive trauma to primary teeth [1]. The etiologic factor of the trauma involving many primary teeth are variable and of particularly high seriousness, with necessary hospital intervention in some of the cases.

Luxation injuries are widely described in the primary dentition, as they are related to the resilience of the alveolar bone and the supporting structures in young children. Avulsion occurs in a prevalence varying from $7 \%$ to $13 \%$ in the primary dentition and children aged $48-60$ months are the most affected [2].

This article reports the diagnosis and management of a complex trauma involving cranial trauma and multiple luxations and avulsions in primary teeth. The treatment strategies are reported up to the 5 years-follow up and the clinical approaches are discussed.

\section{Case Report}

A 5-year-old boy, who resides in a rural area, arrived at the Hospital of Araçatuba, Brazil, on July, 2003, after suffering trauma caused by a horse kick on the same day. Clinical and radiographic examinations were performed. Brain concussion with loss of consciousness (Glasgow coma scale $=11$ ) was diagnosed. The clinical examination revealed edema and contusion in the upper lip and multiple abrasion injuries in face. Bleeding from the nose and mouth was also observed. The intraoral examination revealed multiple dentoalveolar traumas with teeth avulsions $(51,52,53,54,61,62,74,84)$. Tooth 41 also suffered avulsion but could not be reimplanted because it was lost at the location of the accident. Lateral luxation were observed in teeth number $71,72,73,82$ and 83.

Radiographic and tomography examinations were performed to detect the presence of bone fractures These tests revealed no fractures of facial bones, only a dentoalveolar bone injury and soft tissue injury. The surgery was performed under general anesthesia using orotracheal intubation. We extract the teeth with severe mobility and part of the alveolar process. The soft tissue wounds were repaired. The patient remained hospitalized for nine days until neurological recovery.

The child was then referred to the Department of Pediatric Dentistry of Araçatuba Dental School of São Paulo State University for postoperative clinical follow-up. The intra-oral examination showed an adequate postoperative situation. The sutures were removed and periapical radiographs of the involved regions were taken. The parents were instructed about oral hygiene of the child.

Twelve months later, teeth 75 and 85 teeth were banded and a lingual arch was applied. At this time, a panoramic radiograph was taken to observe the position of the succedaneous permanent teeth.

Bimonthly clinical monitoring and radiographic follow-up was done to observe the eruption of permanent teeth. Five years and three months after the accident, the anterior superior and lower permanent teeth had completed their eruption, presenting an adequate position in the arch. White discoloration of enamel with hypoplasia was detected in teeth $11,12,14$ and 22. A panoramic radiography revealed satisfactory eruption of the remaining permanent teeth.

\section{Discussion}

This case report described the management of a multiple dentoalveolar trauma in a 5 year-old boy as well as the five year follow up after the accident.

There are no reports describing the occurrences of dental-alveolar trauma in the primary dentition associated with intra-cranial injuries, being these cases mostly associated with trauma in permanent dentition [3].

Motorcycles, bicycles and pedestrians accidents account for $50 \%$ of the skull-brain trauma in children [4]. Injuries with animals associated incidents are not frequent, especially those affecting primary teeth. The initial diagnosis in the current report was skull-brain trauma with loss of consciousness, with the etiologic factor of a horse kick which affected the face and the head of the child [5]. This report involved multiple luxations and avulsions of primary teeth, as well as the avulsion of the

*Corresponding author: Dr. Robson Frederico Cunha, Department of Pediatric Dentistry, Faculdade de Odontologia de Araçatuba UNESP - Univ Estadual Paulista R. José Bonifácio, 1193, CEP: 16.015-050 Araçatuba, São Paulo, Brazil, Tel: 5518 3636-3235; E-mail: cunha@foa.unesp.br

Received September 03, 2012; Accepted September 24, 2012; Published September 26, 2012

Citation: da Silva Assunção LR, Bianco KG, Silva PIS, Favretto CO, Cunha RF (2012) Multiple Trauma in a 5 Years Child with a Longitudinal Follow Up. J Trauma Treat 1:145. doi:10.4172/2167-1222.1000145

Copyright: (c) 2012 da Silva Assunção LR, et al. This is an open-access article distributed under the terms of the Creative Commons Attribution License, which permits unrestricted use, distribution, and reproduction in any medium, provided the original author and source are credited. 
Citation: da Silva Assunção LR, Bianco KG, Silva PIS, Favretto CO, Cunha RF (2012) Multiple Trauma in a 5 Years Child with a Longitudinal Follow Up. J Trauma Treat 1:145. doi:10.4172/2167-1222.1000145

Page 2 of 2

lower right permanent central incisor which had already erupted prior to the accident. No permanent tooth was lost after the impact.

The follow up period, including the installation of an orthodontic appliance, was important in avoiding disturbances during eruption of the succedaneous teeth. The lingual arch was applied to preserve low arch space. As the child presented an age next to the permanent teeth eruption stage, there was no need of an esthetic space maintainer in both the superior and inferior arches.

\section{References}

1. Oliveira LB, Marcenes W, Ardenghi TM, Sheiham A, Bönecker M (2007)
Traumatic dental injuries and associated factors among Brazilian preschool children. Dent Traumatol 23: 76-81.

2. Freitas MC, Castilho AR, Marta SN, Francischone LA, Carrara CE et al. (2008) Consequences and treatment after multiple avulsions of deciduous teeth - a case report. Dent Traumatol 24: e381-e384.

3. Andreasen JO, Ravn JJ (1971) The effect of traumatic injuries to primary teeth on their permanent successors. Scand J Dent Res 79: 284-294.

4. Akama MK, Chindia ML, Macigo FG, Guthua SW (2007) Pattern of maxillofacia and associated injuries in road traffic accidents. East Afr Med J 84: 287-295.

5. Broman HS and Michael ME (eds.) (1995) Traumatic Head Injury in Children. (1stedn), Oxford University Press, New York. 